\title{
Információs és kommunikációs technológiák alkalmazása dementiában szenvedők komplex ellátásában
}

\author{
Osváth Péter dr. - Kovács Attila dr. - Boda-Jörg Adrienn \\ Tényi Tamás dr. - Fekete Sándor dr. - Vörös Viktor dr. \\ Pécsi Tudományegyetem, Általános Orvostudományi Kar, Klinikai Központ, \\ Pszichiátriai és Pszichoterápiás Klinika, Pécs
}

\begin{abstract}
A modern információs és kommunikációs eszközök egyre inkább a mindennapok nélkülözhetetlen részeivé válnak. Kutatási adatok bizonyítják, hogy az egészség megőrzése és helyreállítása érdekében is eredményesen alkalmazhatók, nemcsak a fiatalok, de az idősebbek körében is, hiszen mára az idősek között is jelentősen elterjedt az internet használata, az egészségügyi alkalmazások azonban kevésbé ismertek. Ez projektünk jelentőségét támasztja alá, hiszen kiemelt fontossággal bír a betegségspecifikus egészségügyi alkalmazások kialakítása és megismertetése. Előzetes felméréseink arra is utaltak, hogy a férfiak erre kevésbé nyitottak, így az ő esetükben specifikus módszerek szükségesek az elektronikus eszközök alkalmazásának elősegítése érdekében. A nagy arányú internetes aktivitás és az információs és kommunikációs érdeklődés megbízható alapot nyújt ezeknek az új technológiáknak az idősek körében való alkalmazására. Így kutatásunk segítségével olyan - a biopszichoszociális alapelveken nyugvó - komplex ellátási modellt tudunk kidolgozni, mely jelentős előrelépést jelenthet az időskori mentális zavarok megelőzésében és korai felismerésében, valamint a dementiával élők és családjuk testi és lelki terheinek enyhítésében.
\end{abstract}

Orv Hetil. 2018; 159(24): 965-973.

Kulcsszavak: dementia, információs és kommunikációs technológia, komplex ellátás

\section{Information and communication technologies in the integrated care of people with dementia}

Modern information and communication tools have increasingly become an indispensable part of our everyday life. Research data demonstrate that it can be used effectively to preserve and restore health, not just among young people but also among the elderly, as for nowadays the use of the internet is widespread among the elderly, but healthcare applications are less well-known. This supports the significance of our project since it is important to develop and introduce disease-specific healthcare applications. Our preliminary results also indicated that men are less open to these new technologies, so in their case, specific methods are needed to facilitate the use of electronic devices. The high level of internet activity and the interest in information and communication technologies provide a reliable basis for applying these new technologies to the elderly. Thus, based on our research, we can develop a complex model of care based on the bio-psycho-social principles, which can be a significant advance in the prevention and early detection of age-related mental disorders and in alleviating the physical and psychological burdens of people with dementia and their families.

Keywords: dementia, information and communication technology, integrated care

Osváth P, Kovács A, Boda-Jörg A, Tényi T, Fekete S, Vörös V. [Information and communication technologies in the integrated care of people with dementia]. Orv Hetil. 2018; 159(24): 965-973.

(Beérkezett: 2018. február 8.; elfogadva: 2018. március 19.) 


\section{Rövidítések}

IKT = információs és kommunikációs technológia; RKV = randomizált-kontrollált vizsgálatok

\section{Infokommunikációs robbanás az egészségügyben}

$\mathrm{Az}$ információs és kommunikációs technológiai (IKT) robbanás nemcsak mindennapi életünket formálta át, de a társadalmi-kulturális kommunikációs sajátosságokat is, így az egészségügyi ellátásban is jelentős változásokat eredményezett. Ennek következtében a telemedicina (e-health) és a telepszichiátria (e-mental health) területén egyre intenzívebb kutatások kezdődtek, hogy minél többet megtudjunk a gyógyítás új eszközeiről, ennek előnyeiről és negatív következményeiről, valamint az orvos-beteg kapcsolat változásairól. Ezek az eszközök sokkal szélesebb körü és intenzívebb kapcsolattartást tesznek lehetővé a segítőszolgálatokkal, és korábban elképzelhetetlen mennyiségú és változatos minőségü (de sokszor megbízhatatlan) információval árasztják el a felhasználókat [1]. Az internetes pszichoedukációs lehetőségek, a kezeléssel való együttmúködést támogató programok, az önsegító módszerek - mint a hagyományos orvos-beteg kapcsolat kiegészítői - egyre nagyobb segítséget jelentenek a gyógyítás eredményességének növelésében. A leggyakoribb infokommunikációs eszközöket és alkalmazási lehetôségeiket az 1. táblázatban foglaltuk össze.

A mobil és okoseszközök (okostelefon, táblagép, okosóra vagy okoskarkötő stb.) széles körben való elterjedésének köszönhetően folyamatosan monitorozhatjuk testi és lelki állapotunkat, és követhetjük is ezek változásait. Ma már számos élettani paraméter egyszerú módon vizsgálható, mint például a pulzus, a vérnyomás, a bőrellenállás, a légzésszám, a testhőmérséklet vagy éppen az agyi aktivitás. A számítógépes alkalmazások pedig lehetővé teszik, hogy ezeknek a jellemzőknek az elemzésével megbízható információkat nyerjünk az aktuális testi és lelkiállapotra vonatkozóan. Ígéretes kutatási eredmények utalnak arra, hogy a depresszió, a pánikbetegség, az alvászavar vagy éppen a közelgő epilepsziás roham is korán észlelhető. Az orvossal való online kapcsolat révén nemcsak a tünetek korai felismerésére nyílik esély, de sokkal hamarabb kaphatunk segítséget, és követhetô a javulás folyamata is [2]. Az egészségügyi mobilapplikációk és -szenzorok - a felhasználók igényeihez igazodva - a legváltozatosabb funkciókkal bírnak (a mozgás és az aktivitás mérése, az alvás monitorozása, a táplálkozás és az egészséges életmód támogatása, hangulatértékelés, stresszmenedzsment stb.). A páciens állapotának követése azonban nemcsak saját magának, de hozzátartozói vagy gondozói számára is komoly segítséget nyújthat, hiszen az online felügyelet azonnal jelzi, amikor sürgős beavatkozás szükséges (például, ha a gondozásra szoruló rosszul lesz, veszélynek teszi ki magát, vagy elkóborol).

Az orvosokkal (diagnosztikus és terápiás lehetőségek) és a betegtársakkal (például online betegfórumok) való interaktív kommunikáció szintén beláthatatlan távlatokat nyit a gyógyításban [1]. A különböző önkitöltő és szenzoros értékelőprogramok pedig az önreflexió, illetve az önkontroll erôsítése révén segítik az egészségtudatosabb életmód kialakítását és így az életminőség javítását is. A technika azonban nem pótolja, hanem kiegészíti a professzionális segítségnyújtást. A segítók szakértelmét és támogatását az információs és kommunikációs technológiák (IKT) alkalmazásával ötvöző integrált ellátási modellben ez a kétféle megközelítés egymást erősítve járul hozzá a páciensek ellátásának és életminőségének javításához [3].

A modern IKT-eszközök széles körú online adatgyújtést is biztosítanak, így a korábban elképzelhetetlen méretű és minőségú adatbázisok („big data”) elemzése új kutatási irányokat nyithat a medicinában, ami nagy előrelépést jelenthet az egyénre szabott gyógyítás felé [4] (1. táblázat).

1. táblázat |Az információs és kommunikációs eszközök fajtái és felhasználási lehetôségei

\begin{tabular}{lll}
\hline Eszközök & Felhasználás & Előnyök \\
\hline - Személyi számítógép & - Online kommunikáció & - Orvos-beteg kapcsolat kiegészítése \\
- Laptop & - Pszichoedukáció & - Adekvát információközlés a betegségról és a kezelésröl \\
- Táblagép & - Támogató programok & - Folyamatos kapcsolattartás a családtagokkal \\
- Okostelefon & - Önsegítő közösségek & - Testi-lelki állapotromlás korai jeleinek felismerése \\
\hline - Okosóra & - Élettani paraméterek követése (vérnyo- & - Testi funkciók változásának követése \\
- Okoskarkötő & más, pulzus, oxigenizáció, légzésszám, & - Allapotromlás korai felismerése és vészhelyzeti riasztás \\
- Szenzorok & testhömérséklet, börellenállás stb.) & (például szívritmuszavar) \\
& - Alvás, mozgás, aktivitás mérése & - Egészséges életmód elösegítése (mozgás, napi \\
\hline - Egészségügyi applikációk & - Helymeghatározás & aktivitás, táplálkozás, alvás) \\
\hline Szenzoros és önkitöltő módszerek & - Testi és lelkiállapot monitorizálása & - Hangulatértékelés \\
- Szoftverek & - Tünet- és stressznapló & - Stresszmenedzsment \\
\cline { 2 - 3 } & - Online adatgyújtés & - Testtudatosság, önreflexió, önkontroll növelése \\
\hline
\end{tabular}




\section{Öregedő társadalom - az egészségügyi ellátás kihívásai}

A XXI. században a fejlett társadalmakban egyre nő a várható élettartam, és az idősödő populáció a magasabb életkort is jó egészségben és életminőségben szeretné megélni. Ezzel szemben egyre több betegséggel és ezek negatív következményeivel kell megküzdeniük, ami nemcsak életminőségüket rontja, de sokszor önállóságuk elvesztéséhez vezet, így egyre nagyobb arányban szorulnak hozzátartozóik vagy professzionális gondozók segítségére. Az elöregedő európai lakosság növekvő százaléka szenved kognitív problémáktól, ez egyre nagyobb egészségügyi és társadalmi problémát okoz. A WHO 2014ben közzétett jelentése szerint a dementia az egyik legnagyobb közegészségügyi kihívás, mellyel nemcsak a felnövekvő, hanem a mostani generációknak is szembe kell nézniük. A kutatások szerint jelenleg körülbelül 44 millió ember él dementiával, mely szám 2030-ra megduplázódik, 2050-re pedig megháromszorozódik [5]. Pontos hazai epidemiológiai felmérések ugyanakkor nem állnak rendelkezésre, magyar kutatók becslése alapján hazánkban a dementiában szenvedők száma több százezresre (valahol 100-500 ezer között) tehető [6]. Pontos hazai adatok a dementiaellátás direkt (például hospitalizáció, pszichés és szomatikus szövődmények kezelése stb.) és indirekt (például gondozó hozzátartozó munkából való kiesése stb.) költségeiről sem állnak rendelkezésre.

Fontos hangsúlyoznunk a komorbiditás jelentőségét, ugyanis a kognitív zavarokkal élő emberek életminősége tovább romlik, ha egyidejüleg más betegségben (mint például Parkinson-kórban) is szenvednek. A betegségek tünetei jelentősen rontják a mindennapi életminőséget, ami különösen az egyedül élők esetében okoz komoly problémákat. Az Európai Unióban a 80 év feletti lakosság 3,3\%-a él ellátóotthonokban, körülbelül 35\%-uk párkapcsolatban él otthonában, de közel 50\%-uk egyedül lakik [5]. Ez az arány jól mutatja, hogy az öregedő lakosság, az ellátórendszer, illetve a hozzátartozók körében komoly igény merül fel az egyedül élő idősek komplex és hatékony gondozásának megszervezésére. Hiszen a krónikus betegségek az érintett környezetére is jelentős hatással vannak, a betegségek progressziója miatt a hozzá-

2. táblázat |Az információs és kommunikációs eszközök felhasználási lehetôségei időskorban

\begin{tabular}{|c|c|c|}
\hline Eszköz és az alkalmazás típusa & Felhasználás & Elönyök \\
\hline \multicolumn{3}{|l|}{ Aktív eszközök } \\
\hline \multirow{11}{*}{$\begin{array}{l}\text { - Személyi számítógép } \\
\text { - Laptop } \\
\text { - Táblagép } \\
\text { - Okostelefon }\end{array}$} & - Online kommunikáció & - Izoláció oldása \\
\hline & - Folyamatos és intenzív kapcsolattartás a & - Biztonságérzet növelése \\
\hline & családtagokkal & - Családi és baráti kapcsolatok erősítése \\
\hline & - Telemedicinás módszerek & - Online segítségnyújtás, tanácsadás \\
\hline & & $\begin{array}{l}\text { - Korai kezelésbe vétel és kapcsolattartás (különösen fontos } \\
\text { mozgáskorlátozottság esetén) }\end{array}$ \\
\hline & & - Orvos-beteg kapcsolat kiegészítése \\
\hline & & - Gyógyszeres kezeléssel való együttmúködés javítása \\
\hline & _ Pszichoedukáció & _- Beteoséogel és kezeléssel kancsolatos információközlés \\
\hline & - Interaktív oktatóprogramok & - Prevenció, egészségtudatos magatartás fejlesztése \\
\hline & $\begin{array}{l}\text { - Kognitív, memória-, problémamegoldó, } \\
\text { relaxációs és asszertivitástréning }\end{array}$ & - Testi-lelki egyensúly megőrzése \\
\hline & - Online önsegítő közösségek & - Kapcsolati háló erősítése \\
\hline - Számítógépes játékok & $\begin{array}{l}\text { - Szórakoztató időtöltés } \\
\text { - Kognitív készségek fejlesztése és követése }\end{array}$ & - Kognitív hanyatlás korai felismerése \\
\hline \multicolumn{3}{|l|}{ Passzív módszerek } \\
\hline - Okosóra & - Telemonitoring & - Egészségtudatosság növelése \\
\hline - Okoskarkötő & - Élettani paraméterek követése (vérnyomás, & - Egészséges életmód elősegítése (mozgás, napi aktivitás, \\
\hline - Szenzorok & pulzus, oxigenizáció, légzésszám, & táplálkozás, alvás) \\
\hline & testhőmérséklet, bőrellenállás stb.) & - Önállóság és a biztonság növelése \\
\hline & - Alvás, mozgás, aktivitás mérése & - Testi funkciók változásának követése \\
\hline & - Helymeghatározás & - Állapotromlás korai felismerése és vészhelyzeti riasztás \\
\hline & & - Elesés rizikójának mérséklése \\
\hline & & - Elkóborlás felismerése és megelőzése \\
\hline \multirow[t]{4}{*}{ - Biztonsági berendezések } & - Ajtónyitást jelző szenzorok & - Környezet biztonságossá tétele \\
\hline & - Füst- és tűzérzékelők & - Online felügyelet \\
\hline & - Mozgásérzékelő világítás & - Hozzátartozók és gondozók terheinek enyhítése \\
\hline & - Biztonsági webkamerák & - Stresszcsökkentés \\
\hline \multirow{3}{*}{$\begin{array}{l}\text { - Funkciókiesést kompenzáló } \\
\text { eszközök }\end{array}$} & - Robotinas & - Önellátás facilitálása \\
\hline & - Tervező- és irányító-, tájékozódást segítő & - Napi aktivitás elősegítése \\
\hline & programok & - Funkcionálás és közlekedés biztonságosabbá tétele \\
\hline
\end{tabular}


tartozóktól és a gondozóktól egyre nagyobb anyagi, időbeli, szellemi és fizikai erőfeszítést kíván a megfelelő és biztonságos ellátás megszervezése. A jelenlegi demográfiai trendeket figyelembe véve az ellátórendszer finanszírozhatósága és fenntarthatósága egyre komolyabb kihívást jelent mind a humán, mind az anyagi erőforrások szempontjából. Ezért mind nagyobb szükség van olyan komplex programokra, amelyek az ellátásban részt vevők (költség)hatékony együttműködésének megvalósításán keresztül az életminőség és az önállóság minél hosszabb ideig tartó megőrzését tűzik ki célul.

\section{Infokommunikációs eszközök alkalmazása a dementiával élők komplex ellátásában}

Az új IKT fejlődésének köszönhetően ezek az eszközök páratlan lehetőséget nyújtanak a kognitív hanyatlással élő és segítségre szoruló idősek ellátásának javítására (2. táblázat). Az IKT alkalmazása nemcsak hétköznapi életüket könnyíti meg, de jelentősen csökkenti az ellátás költségeit is $[7,8]$. Az IKT által nyújtott megoldások csökkentik a sürgősségi ellátás gyakoriságát, a kórházi felvételek számát és a kórházi tartózkodás idejét [9]. Segítséget nyújtanak az idősek képességeinek megőrzésében, a hétköznapi funkcionálás javításában és az önállóság megőrzésében is. Így a dementiában szenvedők hosszabb ideig élhetnek szeretteik körében, kedvező esetben így nem válik szükségessé a szociális otthonban való elhelyezés [10].

Az IKT-eszközök alkalmazásában rejlő további lehetőségeket támasztja alá, hogy az idősek egyre nagyobb hányada érdeklődik a digitális kultúra iránt. Nemcsak elektronikus levelezést folytatnak, vagy szövegszerkesztőt használnak, de fényképeket is megosztanak, skype-olnak, blogokat és multimédiás alkotásokat készítenek, és számítógépes játékokkal szórakoztatják magukat [8]. Ezen adatok is bizonyítják, hogy a segítő IKT-eszközök az idősek ellátásában is fontos szerephez juthatnak (2. táblázat).

Az infokommunikációs technológiákat az egészségügyi ellátás két fó területén alkalmazzák: az egészségi állapot különböző összetevőinek (tünetek, panaszok, az élettani paraméterek és az aktivitás változásai stb.) monitorizálására (telemonitoring), ami nemcsak a korai beavatkozást segíti, de az egészségtudatosságot is fejleszti. Az elváltozások kezelését pedig a teleterápia teszi lehetővé, melynek során az idősek professzionális segítséggel javíthatják egészségi állapotukat [11]. A segítőkkel történő online konzultáció különösen fontos a mozgásukban korlátozott, izolálódott idősek számára. Ezt támasztják alá azok a vizsgálatok is, melyek a rendszeres telefonkonzultáció szuicidprevenciós hatékonyságát bizonyították az idős populációban [12].

$\mathrm{Az}$ egyre intenzívebb kutatások során számos olyan terület körvonalazódott, melyben az IKT-megközelítés segíthet az időseknek, úgymint az önállóság biztosítása, az elesés rizikójának mérséklése, a krónikus testi és men- tális betegségek (például a dementia vagy a depresszió) negatív következményeinek enyhítése és a gyógyszeres kezeléssel való együttmúködés biztosítása, valamint a szociális izoláció oldása és az életminőség javítása $[8$, 13]. Az idősek körében végzett, a különböző információs és kommunikációs eszközök hatását felmérő vizsgálatokat, randomizált-kontrollált vizsgálatokat (RKV) és metaanalíziseket a 3. táblázatban foglaltuk össze [1329].

Elsőként azokat a technikákat kell megemlíteni, amelyekben a modern infokommunikációs eszközök a hatékonyabb információközlést biztosítva segítenek a szociális kapcsolatok fenntartásában és az eredményesebb pszichoedukáció megvalósításában [14, 19]. Az interaktív oktatóprogramok nemcsak naprakész és egyénre szabott információkat biztosítanak az érintetteknek és segítőiknek, de az online kapcsolat révén kognitív viselkedésterápia, problémamegoldó, relaxációs és asszertivitástréning is alkalmazható [20]. Ezek a módszerek jelentős mértékben enyhítik a gondozók érzelmi terheit, utalhatunk például a holland „Mastery over dementia” programra [22]. Eredményességük igazolására azonban további kontrollált vizsgálatok szükségesek [23].

Számos olyan egyéb módszert is vizsgáltak, melyek a kognitív hanyatlással küzdők relaxációját, megfelelő stimulációját, illetve a funkcióromlás kompenzációját segítik speciális applikációk alkalmazásával [24]. Táblagép segítségével a különböző kommunikációs és webprogramokat, játékokat, zenék, képek és filmek lejátszását az időskori agitáció nem farmakológiai kezelésének részeként is alkalmazzák. Ez a komplex módszer súlyosabb kognitív hanyatlás esetén is hatékonynak és biztonságosnak bizonyult [25]. Különösen eredményesek azok az applikációk, melyek a családtagok által összeállított és személyre szabott élményanyagot használják fel (memory box). Ez nemcsak az agitált viselkedést, valamint a depressziós és szorongásos tüneteket mérsékelte, de jelentősen javította a dementiával élők életminőségét is [26]. A memóriatréning speciális formáját jelenti az úgynevezett reminiszcenciaterápia, melynek „off-line” változatát széles körben használják a dementiával küzdők kezelésében. Ennek célja a szociális izoláció oldása, az örömteli és stimuláló tevékenységek elősegítése, az önértékelés javítása és a családi kapcsolatok újrastrukturálása. Nemcsak az örömteli események felidézése, de a veszteségekhez kapcsolódó negatív élmények feloldozása is a részét képezi. Nagy előnye, hogy nemcsak az idősek, de a hozzátartozók számára is segítséget nyújt kapcsolatuk javítására, a professzionális segítők számára pedig a páciens jobb megismerésének lehetôségét biztosítja [24]. Az infokommunikációs technológia, mint például a multimédiás eszközök (videó, zene, képek, narrációval vagy a nélkül) használatának vagy az internetes kommunikációnak az elsajátítása lehetővé teszi a tréninganyagok személyre szabását, és így növelik a módszer hatékonyságát [27]. Hasonlóan eredményesnek találták a különböző IKT-eszközökkel végzett kognitív tréningeket [28, 29], 
3. táblázat |Az információs és kommunikációs eszközök hatását időskorban felmérő vizsgálatok, randomizált-kontrollált vizsgálatok (RKV) és metaanalízisek

\begin{tabular}{|c|c|c|c|c|}
\hline Hivatkozás & Cél & Minta & Módszer & Eredmény \\
\hline \multicolumn{5}{|l|}{ Egyéb vizsgálatok } \\
\hline $\begin{array}{l}\text { Chiu és Eysen- } \\
\text { bach, } 2011\end{array}$ & $\begin{array}{l}\text { Webes pszichoedukáció és } \\
\text { intervenció alkalmazhatóságának } \\
\text { vizsgálata }\end{array}$ & $\begin{array}{l}\text { Demens pácienst } \\
\text { gondozó családtagok } \\
(14 \text { fó) }\end{array}$ & $\begin{array}{l}\text { Mélyinterjús } \\
\text { kvalitatív elemzés }\end{array}$ & $\begin{array}{l}\text { Az intervenciók alkalmazását a } \\
\text { gondozó attitűdje és igényei, } \\
\text { az IKT-eszközök sajátosságai és a } \\
\text { beavatkozás módja egyaránt } \\
\text { befolyásolják }\end{array}$ \\
\hline $\begin{array}{l}\text { Perälä és mtsai, } \\
2013\end{array}$ & $\begin{array}{l}\text { IKT-eszközök hatása a biztonság } \\
\text { növelésére és az elkóborlás } \\
\text { megakadályozására }\end{array}$ & $\begin{array}{l}\text { Alzheimer-dementiában } \\
\text { szenvedő páciensek } \\
\text { (32 fö) }\end{array}$ & $\begin{array}{l}3 \text { éves követéses } \\
\text { vizsgálat }\end{array}$ & $\begin{array}{l}\text { A helymeghatározást és ellenőrzést } \\
\text { biztosító otthoni eszközök növelték } \\
\text { a biztonságot, az önállóságot, } \\
\text { és javították az életminőséget } \\
\text { (elsősorban a dementia korai fázisában } \\
\text { hasznos) }\end{array}$ \\
\hline
\end{tabular}

Schaller és mtsai, Interaktív webfelület (European Alzheimer-dementiában 12 hetes kérdőíves Javult a személyre szabott információk $2016 \quad$ Health Monitor Dementia szenvedő pácienst gondozók (6 fó) és vizsgálat a portál elérése, a gondozók közötti Portal) hozzátartozók (26 fő)

használatának együttmúködés, az egészségügyi ellátás és az ehhez való hozzáférés (a gondozók megterhelése és életminősége nem változott)

\begin{tabular}{|c|c|c|c|c|}
\hline \multicolumn{5}{|c|}{ Randomizált-kontrollált vizsgálatok (RKV) } \\
\hline $\begin{array}{l}\text { Davison és mtsai, } \\
2016\end{array}$ & $\begin{array}{l}\text { Személyre szabott multimédia } \\
\text { program (memory box) } \\
\text { alkalmazásának vizsgálata agitált } \\
\text { viselkedés esetén }\end{array}$ & $\begin{array}{l}\text { Idősek otthonában élő } \\
\text { enyhe, közepes és súlyos } \\
\text { dementiában szenvedő } \\
\text { páciensek ( } 11 \text { fó) }\end{array}$ & $\begin{array}{l}\text { RKV ( } 8 \text { hetes } \\
\text { vizsgálat) }\end{array}$ & $\begin{array}{l}\text { Szorongásos és depressziós tünetek } \\
\text { csökkenése }\end{array}$ \\
\hline $\begin{array}{l}\text { Bloom és mtsai, } \\
2015\end{array}$ & $\begin{array}{l}\text { Internetes pszichoedukáció, } \\
\text { kognitív viselkedésterápia, } \\
\text { problémamegoldó tréning, } \\
\text { relaxáció- és asszertivitástréning }\end{array}$ & $\begin{array}{l}\text { Demens pácienst } \\
\text { gondozó személyek } \\
(245 \text { fó) }\end{array}$ & $\begin{array}{l}\text { RKV ( } 8 \text { alkalom + } \\
\text { utánkövetés) }\end{array}$ & $\begin{array}{l}\text { Szorongásos és depressziós tünetek } \\
\text { csökkenése }\end{array}$ \\
\hline \multicolumn{5}{|l|}{ Metaanalizisek } \\
\hline $\begin{array}{l}\text { Egan és mtsai, } \\
2015\end{array}$ & $\begin{array}{l}\text { Internetes segítőprogramok } \\
\text { (pszichoedukáció, probléma- } \\
\text { megoldó tréning, pszichológiai } \\
\text { támogatás) }\end{array}$ & $\begin{array}{l}\text { Demens pácienst } \\
\text { gondozó személyek }\end{array}$ & $\begin{array}{l}\text { Metaanalízis } \\
\text { (4 tanulmány) }\end{array}$ & $\begin{array}{l}\text { Lehetséges, de nem bizonyított } \\
\text { pozitív hatás a lelki egészségre, } \\
\text { a megküzdésre és az életminőségre }\end{array}$ \\
\hline $\begin{array}{l}\text { Martínez-Alcalá és } \\
\text { mtsai, } 2016\end{array}$ & $\begin{array}{l}\text { IKT alkalmazásának lehetőségei } \\
\text { (passzív és aktív módszerek) }\end{array}$ & $\begin{array}{l}\text { Alzheimer-dementiában } \\
\text { szenvedő páciensek és } \\
\text { gondozók }\end{array}$ & $\begin{array}{l}\text { Metaanalízis } \\
\text { (Alzheimer-demen- } \\
\text { tiában szenvedók } \\
\text { - } 16 \text { tanulmány és } \\
\text { gondozók - } 10 \\
\text { tanulmány) }\end{array}$ & $\begin{array}{l}\text { IKT-módszerek mindkét csoportban } \\
\text { javítják az életminőséget; segít } \\
\text { megérteni a betegség hátterét és } \\
\text { lefolyását; javítja a beteggel való } \\
\text { kapcsolatot }\end{array}$ \\
\hline $\begin{array}{l}\text { García-Casal és } \\
\text { mtsai, } 2017\end{array}$ & $\begin{array}{l}\text { Számítógépes kognitív tréning } \\
\text { hatékonyságának vizsgálata }\end{array}$ & $\begin{array}{l}\text { Dementiában szenvedő } \\
\text { páciensek }\end{array}$ & $\begin{array}{l}\text { Metaanalízis } \\
\text { (20 tanulmány) }\end{array}$ & $\begin{array}{l}\text { A kognitív funkciók és a szorongás } \\
\text { mérsékelt javulása; a depressziós } \\
\text { tünetek kismértékú javulása; a napi } \\
\text { aktivitást nem befolyásolta }\end{array}$ \\
\hline $\begin{array}{l}\text { Khosravi és } \\
\text { Ghapanchi, } 2016\end{array}$ & $\begin{array}{l}\text { Különböző IKT-módszerek } \\
\text { (például telemedicina, kisegítő } \\
\text { technikák, robotika, szenzoriális } \\
\text { technikák) hatása a leggyakoribb } \\
\text { időskori problémákra }\end{array}$ & 60 év feletti idősek & $\begin{array}{l}\text { Metaanalízis } \\
\text { (4l tanulmány) }\end{array}$ & $\begin{array}{l}\text { Javították a krónikus testi betegséggel } \\
\text { élők életminőségét, a dementiában } \\
\text { szenvedők általános állapotát, } \\
\text { az idősek önállóságát, csökkentették } \\
\text { az elesés rizikóját, a szociális izolációt } \\
\text { és a depressziós tüneteket; } \\
\text { a gyógyszeres kezeléssel való } \\
\text { együttmúködésre alig volt hatásuk; } \\
\text { csökkentették a kórházi felvételek } \\
\text { számát, a kezelés idejét és költségeit, } \\
\text { enyhítették a gondozók terheit }\end{array}$ \\
\hline $\begin{array}{l}\text { Jackson és mtsai, } \\
2016\end{array}$ & $\begin{array}{l}\text { Telefonos, internetes és } \\
\text { kombinált intervenciók } \\
\text { hatékonyságának vizsgálata }\end{array}$ & $\begin{array}{l}\text { Különböző típusú } \\
\text { dementiában szenvedő } \\
\text { páciensek gondozói }\end{array}$ & $\begin{array}{l}\text { Metaanalízis } \\
\text { (22 tanulmány: } \\
13 \text { telefonos, } \\
5 \text { internetes és } \\
4 \text { kombinált } \\
\text { intervenciókat } \\
\text { vizsgált) }\end{array}$ & $\begin{array}{l}\text { A kombinált intervenciók voltak } \\
\text { a leghatékonyabbak a depresszió és } \\
\text { az érzelmi terhek csökkentésében és } \\
\text { az önhatékonyság növelésében; } \\
\text { alig vizsgálták a dementiatípusokra } \\
\text { specifikus beavatkozásokat }\end{array}$ \\
\hline
\end{tabular}


3. táblázat folyt.

\begin{tabular}{|c|c|c|c|c|}
\hline Hivatkozás & Cél & Minta & Módszer & Eredmény \\
\hline Hill és mtsai, 2017 & $\begin{array}{l}\text { Számítógépes kognitív tréning } \\
\text { hatékonyságának vizsgálata }\end{array}$ & $\begin{array}{l}\text { Enyhe kognitív } \\
\text { romlásban és dementiá- } \\
\text { ban szenvedő páciensek }\end{array}$ & $\begin{array}{l}\text { Metaanalízis } \\
\text { (17 tanulmány) }\end{array}$ & $\begin{array}{l}\text { A kognitív funkciók mérsékelt javulása } \\
\text { enyhe kognitív hanyatlás esetén; } \\
\text { csekély, de statisztikailag szignifikáns } \\
\text { javulás dementia esetén }\end{array}$ \\
\hline $\begin{array}{l}\text { Wasilewski és } \\
\text { mtsai, } 2017\end{array}$ & $\begin{array}{l}\text { Webes intervenciók } \\
\text { alkalmazásának és hatásának } \\
\text { vizsgálata }\end{array}$ & $\begin{array}{l}\text { Krónikus időskori beteg- } \\
\text { ségekben (különös } \\
\text { tekintettel a dementiára) } \\
\text { szenvedő páciensek } \\
\text { gondozói }\end{array}$ & $\begin{array}{l}\text { Metaanalízis } \\
\text { (53 tanulmány) }\end{array}$ & $\begin{array}{l}\text { Interaktív, egyénre szabott és } \\
\text { betegségspecifikus intervenciók } \\
\text { fontossága (ezek csökkentették a } \\
\text { gondozók érzelmi megterhelését) }\end{array}$ \\
\hline $\begin{array}{l}\text { D’Onofrio és } \\
\text { mtsai, } 2017\end{array}$ & $\begin{array}{l}\text { A napi aktivitást befolyásoló } \\
\text { IKT-eszközök vizsgálata } \\
\text { (segítő webfelületek, „okos- } \\
\text { otthon” és monitoringrend- } \\
\text { szerek, GPS-alapú nyomon } \\
\text { követés és tájékozódás) }\end{array}$ & $\begin{array}{l}\text { Dementiában szenvedő } \\
\text { páciensek és gondozóik }\end{array}$ & $\begin{array}{l}\text { Metaanalízis } \\
\text { (26 tanulmány) }\end{array}$ & $\begin{array}{l}\text { Javult a dementiában szenvedők } \\
\text { otthoni ellátása és a gondozók } \\
\text { életminósége, csökkentek az } \\
\text { egészségügyi költségek és a korai } \\
\text { intézeti elhelyezés esélye }\end{array}$ \\
\hline
\end{tabular}

a videojátékokat [30」, a hang-, szöveg- és képfelismerést [31] vagy akár a virtuális realitást [32] alkalmazó módszereket. A számítógépes tréningek nemcsak enyhe kognitív hanyatlás, de dementia esetén is javították a globális kognitív funkciókat és a visuospatialis képességeket. A memória javítását célzó számítógépes neurokognitív tréning még hatékonyabbnak bizonyult, amikor egyénre szabott módszereket alkalmaztak [33]. Kiemelésre érdemes, hogy a számítógépes játékok nemcsak a kognitív funkciók javításában alkalmazhatók, de költséghatékony és felhasználóbarát szűrővizsgálatként a dementia korai felismerésében is segítséget nyújthatnak [34].

A másik nagy csoportba azok az eszközök tartoznak, melyek az idősek mindennapi tevékenységeit, fizikai és szociális aktivitását támogatják. Idetartoznak a különböző emlékeztetők, az elesést vagy egyéb veszélyhelyzeteket jelző készülékek. Az elektronikus memóriasegítők előre felvett tanácsokkal nyújtanak segítséget a hétköznapi tevékenységek elvégzésében is. Fontos szerephez jutnak a páciensek állapotát monitorozó szenzoriális technikák is. Ezekkel nemcsak a legváltozatosabb élettani paramétereket lehet mérni (mint például vérnyomás, pulzus, oxigénszaturáció), de akár a páciens mozgását és aktivitását [11].

Intenzív kutatások folynak azon a területen is, hogy hogyan csökkenthetik az IKT-eszközök a dementia negatív következményeit. Ezek között az egyik leggyakoribb és legveszélyesebb az elkóborlás. Számos vizsgálat igazolta, hogy a különböző érzékelők (mint például az ajtónyitást jelző szenzorok) és a GPS-alapú nyomkövetők jelentős előrelépést jelentenek ennek megelőzésében [35]. Ennek a módszernek az alkalmazásával csökkenthető az időskori elkóborlás rizikója [21], és sokkal könynyebben meg is található az eltünt személy [36]. A dementiában szenvedők biztonságos otthoni életének kialakításában egyéb érzékelők is szerepet játszanak, mint például a füst- és tűzjelzők, a mozgásérzékelő világítás [21]. A különböző biztonsági eszközök (például füstjelzők, ajtónyitást érzékelő szenzorok, áramütés elle- ni védelem, víz- és levegőhőmérséklet-szabályozás, mozgás- és aktivitásérzékelők, biztonsági webkamerák stb.), a mindennapi funkciócsökkenést kompenzáló berendezések (robotinasok - házimunka végzése, fürdetés, étkezés) és a szociális aktivitást elősegítő programok (telemedicina, e-mail, vagy online kapcsolatok stb.) mellett kiemelt szerephez jutnak a kognitív funkciókat karbantartó lehetőségek (például a realitásorientációs és memóriatréningek). Ennek során az IKT-eszközök segítenek a pácienseknek a saját magukra és környezetükre vonatkozó legfontosabb információk begyakorlásában, mint például a térben és időben való tájékozódás, fontos napi teendők és események, nevek és más személyek megjegyzése [8]. Úgy tűnik, hogy az alkalmazott technológiától függetlenül az eszközök használatát nem annyira a technikai problémák, sokkal inkább a felhasználók kognitív romlása korlátozta, így elsősorban a dementia korai fázisában alkalmazhatók eredményesen [21]. Ez a korai felismerés jelentőségét húzza alá, hiszen az IKT-eszközök használatának elsajátítását a kognitív hanyatlás progreszsziója már jelentősen megnehezítheti. A betegség előrehaladott fázisában inkább a passzív IKT-eszközök váltak be, mint például az ajtóriasztók vagy a különböző kamerák [21].

Napjainkban egyre jobban elterjednek azok a komplex módszerek, melyekben a különböző infokommunikációs technikákat kombinálják az idősek mindennapi életének elősegítése érdekében. Idetartoznak például azok az irányítóalkalmazások, melyek érzékelik a páciens tevékenységét, és a tervező- és az irányítórendszer segítségével facilitálják a napirend szerinti aktivitás elvégzését (mint például a kézmosást) [37]. Ez a gyakorlatban azt jelenti, hogy amikor például a páciens kezébe vesz egy tárgyat, akkor egyben folyamatos iránymutatást is kap, hogy mit kell vele csinálnia $[8]$.

A környezetben való tájékozódást elősegítő multifunkcionális eszközök pedig informálják a felhasználót a legcélszerúbb útvonalról, maximálisan alkalmazkodva az egyéni képességekhez és igényekhez. A tervezés során 
integrálják az aktuális környezeti (időjárás, [tömeg]közlekedési információk, szociális programok stb.) és személyes (fizikális és lélektani állapot: például stresszhelyzet, elesés, eltévedés) információkat, és szükség esetén rugalmasan módosítják a tervezést, vagy akár segítséget hívnak. Ezzel jelentősen megkönnyítik és biztonságossá teszik az idősek szociális aktivitását, enyhe és közepes kognitív hanyatlás esetén is [35] (3. táblázat).

A jelenleg elérhető szakirodalom egyelőre nem különíti el az IKT-k speciális alkalmazhatóságát az egyes dementiatípusokra (Alzheimer-kór, vascularis dementiák, Lewy-testes, Parkinson-betegség stb.) vonatkozóan vagy a dementia súlyosságát (enyhe, közepes, súlyos) illetően. A klinikai ismeretek alapján azonban a kognitív játékok, a digitális interakció monitorozása elsősorban az enyhe kognitív deficit, valamint a szűrés és a korai felismerés során lehet hatékony, míg a különböző szenzoriális, illetve felügyeleti eszközök (ajtónyitásszenzorok, elesésmonitorozás, helymeghatározás stb.) főként az előrehaladott dementiákban alkalmazhatók sikerrel. Parkinson-betegségben ugyanakkor speciális mozgásérzékelőket alkalmaznak, melyek segítségével kitűnően monitorozható a páciensek aktuális mozgásteljesítménye és a gyógyszeres kezelés hatékonysága.

Az IKT-k eddig bemutatott számos potenciális előnye mellett felmerülhet a kérdés, hogy milyen hátrányai, „mellékhatásai” lehetnek az IKT eszközeinek az idős populációra vonatkozóan. A technicizálódás tovább növelheti az idős páciensek izolációját, és indirekt módon csökkenhet a családdal, gondozókkal való személyes kapcsolat. Továbbá hamis biztonságérzetet kelthet, akár a gondozókban, akár a családtagokban, akik így még inkább magukra hagyhatják a demens pácienseket. Emellett, fóleg a játékok és online alkalmazások kapcsán a függőség kialakulásával is számolni kell - kiváltképp igaz ez a Parkinson-kórban szenvedő páciensekre, akik olyan anti-Parkinson-gyógyszerelésben részesülnek, mely növeli a függőség kialakulásának kockázatát.

Összefoglalva a szerteágazó kutatási eredményeket, megállapítható, hogy az IKT-eszközök pozitív hatással vannak az idősek mindennapi életére. Segítséget nyújtanak az egészségi állapot és a szociális funkciók javításában, az életminőség és az önállóság megőrzésében is, így hozzájárulnak a független, változatos és biztonságos életmód kialakításához. Az is bebizonyosodott, hogy a telemedicina és a szenzoriális technikák alkalmazása különösen hatékony az egészségi állapot javításában és a járulékos költségek mérséklésében azáltal, hogy csökkentik az időskori elesések rizikóját és az ismételt hospitalizációkat is [13]. Így komoly segítséget jelentenek abban, hogy az idősek minél tovább élhessenek otthonukban anélkül, hogy veszélynek tennék ki magukat. Ezek az eszközök jelentős mértékben hozzájárulnak a hozzátartozók és a gondozók fizikális és érzelmi megterhelésének csökkentéséhez, így az egész család életminőségének javulásához is.
A kutatások azt is bebizonyították, hogy az IKT-eszközök használata akkor a leghatékonyabb, ha megfelelő elméleti háttér alapján, komplex ellátási modell keretében kerülnek alkalmazásra. Számos szerző hangsúlyozza, hogy a fentiek miatt különösen fontos, hogy az idősek ellátásában részt vevő szakemberek figyelembe vegyék ezeket az új IKT-lehetőségeket, segítsék a felhasználókat ezek elfogadásában, és bővítsék az alkalmazási lehetőségeket.

A jelenlegi kutatások eredményeinek értékelését azonban jelentős mértékben korlátozza, hogy gyakran hiányzik az az elméleti keret, mely alapján lehetővé válhat az IKT-eszközök egyénre szabott kombinációjának alkalmazása. Ráadásul alig állnak rendelkezésre az egyes módszerek hatékonyságát értékelő randomizált-kontrollált vizsgálatok. A különböző etiológiájú és súlyosságú demens alcsoportokban való alkalmazásukra és a járulékos viselkedési és pszichés tünetek kezelésére vonatkozóan sem rendelkezünk megbízható adatokkal. Emiatt további, nagyobb esetszámú, megfelelő elméleti alapokon nyugvó vizsgálatok szükségesek az új infokommunikációs eszközök előnyeinek maximális kiaknázása érdekében [13]. Az IKT-kutatások során kiemelt figyelmet kell fordítani a dementiával élő idősek bevonására, hiszen az általuk adott visszajelzések nélkülözhetetlenek a felhasználóbarát eszközök kifejlesztésében [38].

\section{Kutatási program}

Az eddigi kutatások eredményei igazolták, hogy az infokommunikációs technológia alkalmazása jelentős előrelépést jelenthet a dementiával küzdők ellátásában is. Ennek alapján klinikánk kutatócsoportja egy európai multicentrikus kutatási és fejlesztési programba kapcsolódott be (ICT4Life projekt), melynek fó célja, hogy személyre szóló megoldásokkal segítse elő az idősek lehetőség szerint minél hosszabb ideig tartó - önálló és aktív életvitelét [39]. Kutatócsoportunk fó célja a modern IKT-eszközök alkalmazási lehetőségeinek vizsgálata, hogy ennek alapján komplex programot dolgozzunk ki, mely a felhasználók (idős páciensek, hozzátartozók és a professzionális segítők) igényeihez igazított komplex ellátórendszer megtervezésével és kipróbálásával a jelenlegi helyzet javításának esélyét nyújtja [40]. Célul tűztük ki egy olyan IKT-alapú platform kifejlesztését, mely valós információt nyújt a betegről az ápolásában részt vevők számára (orvosok, ápolók, családtagok), ugyanakkor hozzájárul ahhoz is, hogy ezek az emberek önállóan élhessenek otthoni környezetükben, minél későbbi életkorra tolva ezzel az intézeti elhelyezést. Kezdeményezésünk fó célja az enyhe és közepes fokú dementiában szenvedő betegek életminőségének javítása olyan egyénre szabott - információs és kommunikációs technológiai platform kifejlesztésével, melynek eredményeképpen a páciensek testi és lelkiállapota, aktivitása és önállósága is megőrizhető. Az ellátásnak a személyes igényekhez és szükségletekhez való igazításával és haté- 
konyságának növelésével a hangsúly az otthoni segítségnyújtásra tevődhet át, így csökkenhet az egészségügyi szolgálatok felesleges és inadekvát igénybevétele, valamint lerövidülhet a kórházi kezelések ideje is. Az integrált ellátási modellben a hangsúly a problémák reaktív kezeléséről sokkal inkább a preventív, proaktív, személyre szabott megközelítésre tevődik át [40]. Az IKT-eszközök által szolgáltatott széles körű információk feldolgozása és integrálása növeli a dementia negatív következményeinek elhárítását célzó döntési mechanizmusok hatékonyságát, ami szintén jelentős előrelépést jelent a személyre szabott gondozás megvalósításában.

\section{Következtetés}

A modern információs és kommunikációs eszközök egyre inkább a mindennapok nélkülözhetetlen részeivé válnak. Kutatási adatok bizonyítják, hogy az egészség megőrzése és helyreállítása érdekében is eredményesen alkalmazhatók, nemcsak a fiatalok, de az idősebbek körében is, hiszen mára az idősek között is jelentősen elterjedt az internet használata, az egészségügyi alkalmazások azonban kevésbé ismertek. Ez projektünk jelentőségét támasztja alá, hiszen kiemelt fontossággal bír a betegségspecifikus egészségügyi alkalmazások kialakítása és megismertetése. Előzetes felméréseink arra is utaltak, hogy a férfiak erre kevésbé nyitottak, így az ő esetükben specifikus módszerek szükségesek az elektronikus eszközök alkalmazásának elősegítése érdekében.

A nagy arányú internetes aktivitás és az információs és kommunikációs érdeklődés megbízható alapot nyújt ezeknek az új technológiáknak az idősek körében való alkalmazására. Így kutatásunk segítségével olyan - a biopszichoszociális alapelveken nyugvó - komplex ellátási modellt tudunk kidolgozni, mely jelentős előrelépést jelenthet az időskori mentális zavarok megelőzésében és korai felismerésében, valamint a dementiával élők és családjuk testi és lelki terheinek enyhítésében.

Anyagi támogatás: A közleményhez kapcsolódó kutatómunkát az Európai Unió Horizon 2020 kutatási és innovációs programja támogatja (No. 690090). A közlemény megírása során a szerzők anyagi támogatásban nem részesültek.

Szerzői munkamegosztás: A szerzők a kézirat elkészítésében egyenlő mértékben vettek részt. A cikk végleges változatát valamennyi szerző elolvasta és jóváhagyta.

Érdekeltségek: A szerzőknek nincsenek érdekeltségeik.

\section{Irodalom}

[1] Purebl Gy, Szabó-Tóth MD. Can we do psychotherapy on the internet? [Alkalmazhatunk-e pszichoterápiát interneten keresztül?] Orvostovábbk Szle. 2015; 22: 22-25. [Hungarian]
[2] Györffy Zs. Mobile devices in the health service. [Mobileszközök az egészség szolgálatában.] Available from: http://econsilium.hu/mobileszkozok-az-egeszseg-szolgalataban/ [accessed: January 28, 2018]. [Hungarian]

[3] Chan SR, Torous J, Hinton L, et al. Mobile tele-mental health: increasing applications and a move to hybrid models of care. Healthcare 2014; 2: 220-233.

[4] Torous J, Baker JT. Why psychiatry needs data science and data science needs psychiatry: connecting with technology. JAMA Psychiatry 2016; 73: 3-4.

[5] World Alzheimer Report 2014: Dementia and risk reduction. Available from: https://www.alz.co.uk/research/world-report-2014 [accessed: January 28, 2018].

[6] Érsek K, Kárpáti K, Kovács T, et al. Epidemiology of dementia in Hungary. [A dementia epidemiológiája Magyarországon.] Ideggyógy Szle. 2010; 63: 175-182. [Hungarian]

[7] Owen L, Tierney R, Rtveladze K, et al. Cost-utility analysis of an internet and computer training intervention to improve independence and mental wellbeing of older people. Lancet 2015; 386(Suppl 2): S62.

[8] Marešova P, Klímova B. Supporting technologies for old people with dementia: A review. IFAC-PapersOnLine 2015; 48: 129134.

[9] McLean S, Protti, D, Sheikh A. Telehealthcare for long term conditions. BMJ 2011; 342: d120.

[10] Tomita MR, Russ LS, Sridhar R, et al. Smart home with healthcare technologies for community-dwelling older adults. In: Al-Qutayri MA. (ed.) Smart home systems. ISBN: 978-953307-050-6, InTech, Available from: http://www.intechopen. com/books/smart-homesystems/smart-home-with-healthcaretechnologies-for-community-dwelling-older-adults

[11] Vollenbroek-Hutten M, Jansen-Kosterink S, Tabak M, et al. Possibilities of ICT-supported services in the clinical management of older adults. Aging Clin Exp Res. 2017; 29: 49-57.

[12] De Leo D, Carollo G, Dello Buono M. Lower suicide rates associated with a tele-help/tele-check service for the elderly at home. Am J Psychiatry 1995; 152: 632-634.

[13] Khosravi P, Ghapanchi AH. Investigating the effectiveness of technologies applied to assist seniors: A systematic literature review. Int J Med Inform. 2016; 85: 17-26.

[14] Chiu TM, Eysenbach G. Theorizing the health service usage behavior of family caregivers: A qualitative study of an internetbased intervention. Int J Med Inform. 2011; 80: 754-764.

[15] Martínez-Alcalá CI, Pliego-Pastrana P, Rosales-Lagarde A, et al. Information and communication technologies in the care of the elderly: Systematic review of applications aimed at patients with dementia and caregivers. JMIR Rehabil Assist Technol. 2016; 3: e6.

[16] Schaller S, Marinova-Schmidt V, Setzer M, et al. Usefulness of a tailored eHealth service for informal caregivers and professionals in the dementia treatment and care setting: The eHealthMonitor Dementia Portal. JMIR Res Protoc. 2016; 5: e47.

[17] Jackson D, Roberts G, Wu ML, et al. A systematic review of the effect of telephone, internet or combined support for carers of people living with Alzheimer's, vascular or mixed dementia in the community. Arch Gerontol Geriatr. 2016; 66: 218-236.

[18] D'Onofrio G, Sancarlo D, Ricciardi F, et al. Information and communication technologies for the activities of daily living in older patients with dementia: A systematic review. J Alzheimers Dis. 2017; 57: 927-935.

[19] Petrovic K. Respite and the Internet: Accessing care for older adults in the 21st century. Comput Hum Behav. 2013; 29: $2448-2452$.

[20] Wasilewski MB, Stinson JN, Cameron JI. Web-based health interventions for family caregivers of elderly individuals: A scoping review. Int J Med Inform. 2017; 103: 109-138. 
[21] Perälä S, Mäkelä K, Salmenaho A, et al. Technology for elderly with memory impairment and wandering risk. Ehealth Telecommun Syst Netw. 2013; 2: 13-22.

[22] Bloom MM, Zarit SH, Groot Zwaaftink RB, et al. Effectiveness of an Internet intervention for family caregivers of people with dementia: results of a randomized controlled trial. PLoS ONE 2015; 10: e0116622. Available from: https://doi.org/10.1371/ journal.pone.0116622 [accessed: January 28, 2018]

[23] Egan KJ, Pot AM, Albanese E. A systematic review and metaanalysis of internet-based interventions for carers of persons with dementia: More trials needed. Alzheimers Dement. 2015; 11(Suppl): P222.

[24] Lazar A. Using technology to engage people with dementia in recreational activities. A dissertation submitted in partial fulfillment of the requirements for the degree of Doctor of Philosophy, University of Washington, Washington, 2015. Available from: https://digital.lib.washington.edu/researchworks/bitstream/handle/1773/33607/Lazar_washington_0250E_ 15015.pdf? sequence $=1$ [accessed: January 28, 2018].

[25] Vahia IV, Kamat R, Vang C, et al. Use of tablet devices in the management of agitation among inpatients with dementia: an open-label study. Am J Geriatr Psychiatry 2017; 25: 860-864.

[26] Davison TE, Nayer K, Coxon S, et al. A personalized multimedia device to treat agitated behavior and improve mood in people with dementia: A pilot study. Geriatr Nurs. 2016; 37: 25-29.

[27] Lazar A, Thompson H, Demiris G. A systematic review of the use of technology for reminiscence therapy. Health Educ Behav. 2014; 41(Suppl): S51-S61

[28] García-Casal JA, Loizeau A, Csipke E, et al. Computer-based cognitive interventions for people living with dementia: a systematic literature review and meta-analysis. Aging Ment Health 2017; 21: 454-467.

[29] Hill NT, Mowszowski L, Naismith SL, et al. Computerized cognitive training in older adults with mild cognitive impairment or dementia: A systematic review and meta-analysis. Am J Psychiatry $2017 ; 174: 329-340$.

[30] Anguera JA, Boccanfuso J, Rintoul JL, et al. Video game training enhances cognitive control in older adults. Nature 2013; 501: 97-101.

[31] Barnes DE, Yaffe K, Belfor N, et al. Computer-based cognitive training for mild cognitive impairment: results from a pilot ran- domized, controlled trial. Alzheimer Dis Assoc Disord. 2009; 23: $205-210$.

[32] Manera V, Chapoulie E, Bourgeois J, et al. A Feasibility study with image-based rendered virtual reality in patients with mild cognitive impairment and dementia. PLoS ONE 2016; 11 : e0151487.

[33] Fisher BC. The benefits of neurocognitive training in a diagnosed dementia population: an ongoing study since 2011 . Acta Psychopathol. 2017; 3: 2.

[34] Vallejo V, Wyss P, Rampa L, et al. Evaluation of a novel serious game based assessment tool for patients with Alzheimer's disease. PLoS ONE 2017; 12: e0175999.

[35] Teipel S, Babiloni C, Hoey J, et al. Information and communication technology solutions for outdoor navigation in dementia. Alzheimers Dement. 2016; 12: 695-707.

[36] Miskelly F. Electronic tracking of patients with dementia and wandering using mobile phone technology. Age Ageing 2005; 34: 497-499.

[37] Boger J, Hoey J, Poupart P, et al. A planning system based on Markov decision processes to guide people with dementia through activities of daily living. IEEE Trans Inf Technol Biomed. 2006; 10: 323-333.

[38] Spana M, Hettinga M, Vernooij-Dassen $M$, et al. Involving people with dementia in the development of supportive IT applications: A systematic review. Ageing Res Rev. 2013; 12: 535-551.

[39] Strategic Implementation Plan, 2016 - Strategic Part. http:// ec.europa.eu/research/innovation-union/pdf/active-healthyageing/steering-group/implementation_plan.pdf\#view= fit\&pagemode=none [accessed: January 28, 2018].

[40] Osváth P, Vörös V, Kovács A, et al. Information and communication technologies for the improvement of the quality of life of the elderly - ICT4Life project. [Információs és kommunikációs technikai lehetőségek demenciában szenvedők életminőségének javítására - az ICT4Life projekt.] Psychiatr Hung. 2017; 32: 437-443. [Hungarian]
(Vörös Viktor dr., Pécs, Rét u. 2., 7623 e-mail: voros.viktor@pte.hu)

\section{ÁLLÁSAJÁNLAT}

\section{Visegrádon található rehabilitációs fekvőbeteg ellátást nyújtó szakkórházba keresünk \\ II. sz. Rehabilitációs Medicina Alaptevékenységek Osztályra (mozgásszervi profil) osztályvezető föorvost.}

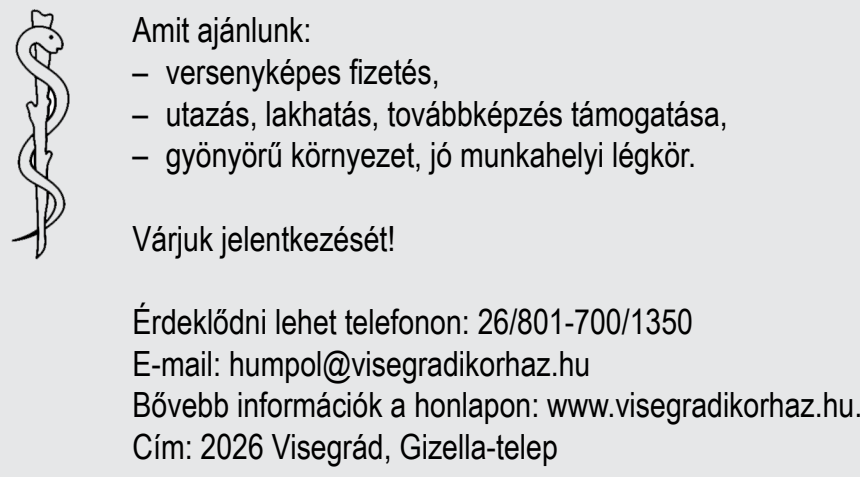

